\title{
Molecular Analyses of Soil Fungal Community - Methods and Applications
}

\author{
Yuko Takada Hoshino \\ National Institute for Agro-Environmental Sciences \\ Japan
}

\section{Introduction}

Fungi play important and diverse roles in soil ecosystems. They act as plant pathogens, mycorrhizal symbionts and most importantly, as the principal decomposers of organic materials (Christensen, 1989; Thorn, 1997). Fungi also represent a dominant component of the soil microflora in terms of biomass (Thorn, 1997). Compared with bacterial communities, however, knowledge regarding the diversity and functions of soil fungal communities remains limited.

Culture-independent molecular techniques, comprising of direct DNA extraction from soil followed by PCR and electrophoresis or cloning, have been introduced to investigate soil fungal communities (Anderson \& Cairney, 2004). These techniques facilitate the detection of fungi, including fastidious or non-culturable strains, and an understanding of the fungal community structures and dynamics in soil (Hoshino \& Matsumoto, 2007; Vandenkoornhuyse et al., 2002).

Molecular techniques have provided novel insights and significant advances in research on soil fungal ecology and have been applied to various soils in different ecosystems, such as forests (Perkiomaki et al., 2003), grasslands (Brodie et al., 2003), dunes (Kowalchuk et al., 1997), stream sediments (Nikolcheva et al., 2003) and agricultural fields (Gomes et al., 2003). For example, in agricultural soils, a fungal community is affected by plant growth (Gomes et al., 2003) and cultural practices, such as application of fertilizers and pesticides (Girvan et al., 2004).

With the development of new technologies, accumulating molecular data has contributed to the establishment of database combined with other environmental data and facilitated metaanalysis on a large scale. In agricultural soils, fungal communities are directly and indirectly related to crop production. Technological advances in molecular methods would help elucidate such a complicated relationship. Here I present molecular techniques applied to soil fungal community analyses, particularly in agricultural soils and discuss their limitations and future applications.

\section{Molecular analysis techniques}

In culture-independent molecular analysis of microbial community, DNA directly extracted from soil may be analyzed by PCR-based techniques targeting specific genes and by metagenomic approach using direct sequencing (Suenaga, 2011). For fungal community 
analyses, PCR-based techniques have been widely and generally used (Anderson \& Cairney, 2004; Hoshino \& Matsumoto, 2007). Fig. 1 showed the experimental scheme of PCR-based molecular analyses for soil fungal community, which consist of three steps: (i) direct extraction of DNA or RNA from soil, (ii) polymerase chain reaction (PCR) amplification of the $18 \mathrm{~S}$ rRNA gene (rDNA) and internal transcribed spacer (ITS) region using fungal specific primers, and (iii) community profiling, including some electrophoresis techniques and sequence based techniques.

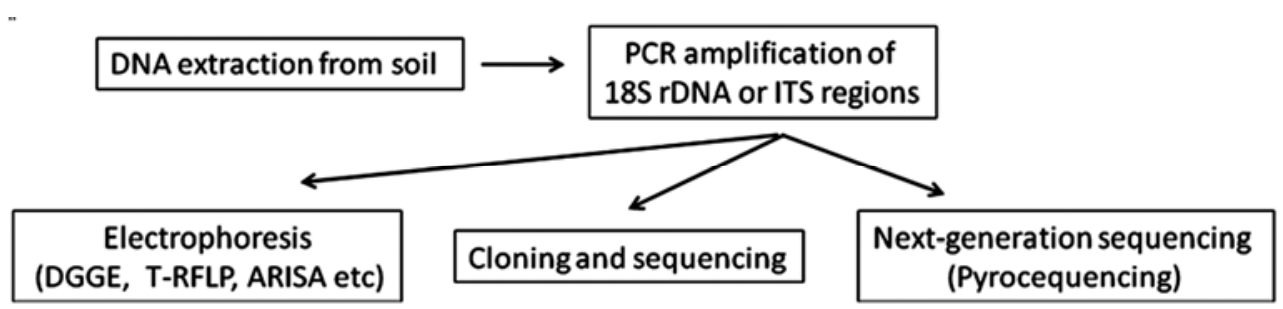

Fig. 1. Experimental scheme: molecular analyses of soil fungal community

\subsection{DNA/RNA extraction}

Many protocols for DNA/RNA extraction from soil have been developed (Robe et al., 2003) and used to extract fungal genomic DNA and fungal RNA. The majority of the direct extraction is the combination of chemical and/or enzymatic treatments and physical procedures. Bead-beating is most effective in cell disruption (Miller et al., 1999) and commercially available kits include this step (Borneman et al., 1996). In these procedures, soil samples are shaken vigorously with small glass beads in buffer including detergent. Microbial cells are disrupted within the soil matrix, and nucleic acids are released from lysed cells. DNA or RNA is, then, recovered and purified.

Because of soil diversity in terms of property and composition, extraction protocol of nucleic acids needs to be optimized for each soil type. For example, it was difficult to extract nucleic acids from Andisol, volcanic ash soils, which strongly adsorbed nucleic acids. The addition of adsorption competitors to the extraction buffer enabled to extract DNA and RNA, and increased the yield of DNA and RNA. From a variety of Andisols, we successfully extracted DNA and RNA for molecular analyses by using skim milk or RNA for DNA extraction (Fig.2A) (Hoshino \& Matsumoto, 2004) and DNA for RNA extraction as adsorption competitors (Fig.2B) (Hoshino \& Matsumoto, 2007).

The DNA extraction protocols, especially with different conditions of cell disruption, can affect the result: Martin-Laurent et al. (Martin-Laurent et al., 2001) showed that microbial community profiles were variable, according to DNA recovery methods used, both in terms of phylotype abundance and the composition of indigenous bacterial community. Soil sample size may also influence analysis results targeting fungal community. Ranjard et al. (Ranjard et al., 2003) reported that analytical results of fungal community structure varied among replicates from a single homogenized soil sample when sample size was less than 1 $\mathrm{g}$, while sample range between 0.125 - $4 \mathrm{~g}$ had no effect on the assessment of bacterial community structure.

We also observed significant variation in fungal community profiles among replicates of the conventional sample size of $0.4 \mathrm{~g}$ soil from a single homogenized sample for DNA 
extraction, using commercially available kit (Fig. 3B), while such variation was not detected in bacterial community profiles (Fig. 3A), using denaturing gradient gel electrophoresis (DGGE), a community profiling method (see Section 2.3 ).
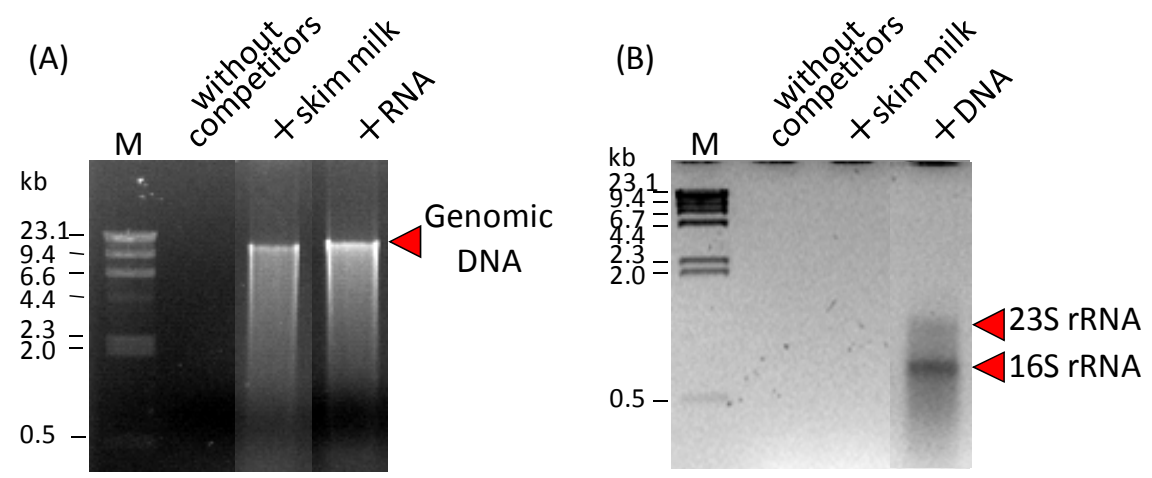

Fig. 2. Improvement of DNA and RNA extraction from Andisols, using adsorption competitors

(A)

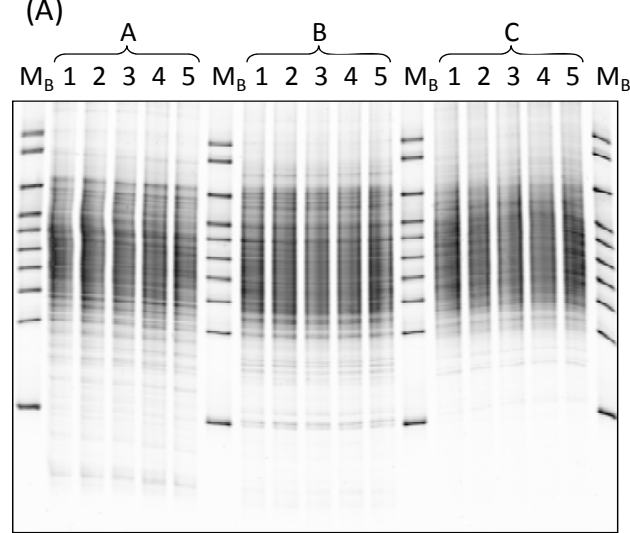

(B)

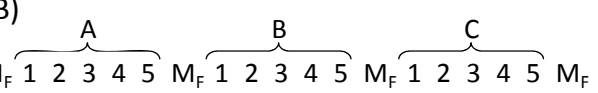

Fig. 3. Variation in bacterial (A) and fungal DGGE profiles (B) among replicates (1-5) from $0.4 \mathrm{~g}$ of soil from a single homogenized sample. Soils A and B were taken from upland fields, and soil $C$ from a paddy field. $M_{B}$ : Marker for bacterial DGGE, $M_{F}$ : Marker for fungal DGGE Increasing sample size and pre-treatments for homogenization of soil samples decreased variation in fungal DGGE profiles among replicates (Fig. 4). Sample size increased by mixing DNA extracts from $0.4 \mathrm{~g}$ soil to rule out the influence of sample size on the efficacy of DNA extraction (Fig. 4A). With regard to pre-treatment for soil homogenization, we found that grinding in liquid nitrogen was suitable for upland field soils while adding buffer to soil to obtain homogeneous soil suspension was suitable for paddy filed soils. These pretreatments did not significantly affect fungal DGGE profiles under the experimental conditions (Fig. 4B). 
(A)

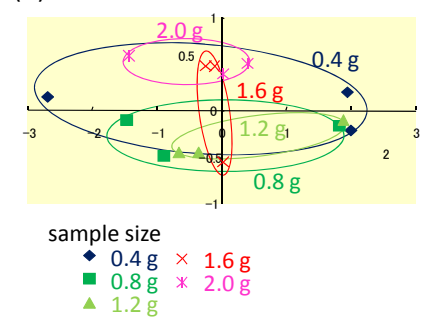

(B)

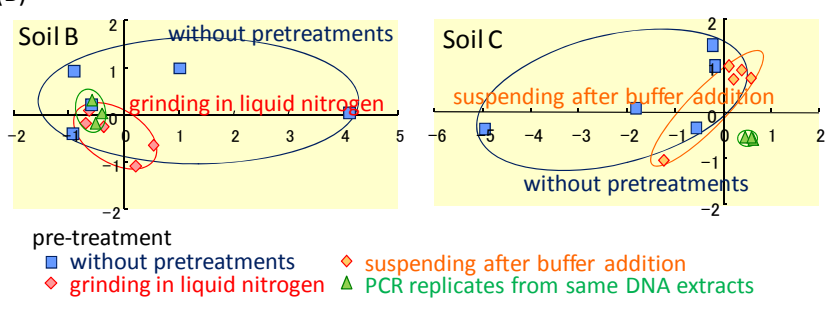

Fig. 4. Multi-dimensional scaling (MDS) map based on the similarities of fungal DGGE profile among replicates when increasing soil sample size from 0.4 to $2.0 \mathrm{~g}(\mathrm{~A})$ and when grinding in liquid nitrogen or suspending after buffer addition was done as a pre-treatment (B). In MDS map the closer the points to each other, the more similar the DGGE banding patterns represented by the points

\subsection{PCR amplification of fungal genetic markers}

Ribosomal RNA genes (rDNA), especially the small subunit ribosomal RNA genes, i.e., $18 \mathrm{~S}$ rRNA genes (18S rDNA) in the case of eukaryotes, have been predominant target for the assessment of microbial community (Kowalchuk et al., 2006). The large subunit ribosomal RNA genes, 28S rDNAs, have been also targeted (Möhlenhoff et al., 2001) but been used less frequently than $18 \mathrm{~S}$ rDNAs. The following properties of rDNAs are suitable for taxonomic identification: (i) ubiquitous presence in all known organisms; (ii) presence of both conserved and variable regions; (iii) the exponentially expanding database of their sequences available for comparison. In community analysis of environmental samples, the conserved regions serve as annealing sites for the corresponding universal PCR primers, whereas the variable regions can be used for phylogenetic differentiation. In addition, the high copy number of rDNA in the cells facilitates detection from environmental samples.

However, the lack of relative variation within $18 \mathrm{~S}$ rDNA genes among closely related fungal species results in taxonomic identification commonly limited to genus or family level. For higher resolution in taxonomic identification, the internal transcribed spacer (ITS) region, which located between the $18 \mathrm{~S}$ rDNA and $28 \mathrm{~S}$ rDNA has been targeted (White et al. 1990; Gardes \& Bruns, 1993). The ITSs, non-coding regions, have greater sequence variation among closely related species than the coding regions of rRNA genes because of their fast late of evolution. Protein-coding functional genes have been also employed as genetic markers to target a specific functional group (Ascomycetous laccase; Lyons et al., 2003) or to get higher resolution in specific fungal taxa (Fusarium elongation factors; Yergeau et al., 2005).

These genetic markers were amplified from soil DNA or RNA by PCR using fungal specific primers. Various PCR primer sets targeting fungal sequences are now available (Anderson \& Cairney, 2004). Selection of PCR primer is one of the most important factors affecting outcome in fungal community analysis (Jumpponen, 2007; Hoshino \& Morimoto, 2010). The properties of PCR primers will be described in Section 3.

\subsection{Community profiling methods}

PCR products are the mixtures of target genes, such as the rDNA and ITS region, derived from various kinds of fungi and are often of very similar size, differentiation must be 
achieved on the basis of the nucleotide composition. The compositions of these PCR products were analyzed by community profiling methods, including some electrophoresis techniques, such as denaturing gradient gel electrophoresis (DGGE), temperature gradient gel electrophoresis (TGGE), terminal restriction fragment length polymorphism analysis (TRFLP), and automated ribosomal intergenic spacer analysis (ARISA), and sequence based techniques, such as cloning and sequencing and second-generation sequencing technologies (Nocker et al., 2007). Here we introduce the principles and the properties of the commonly used community profiling methods.

\subsubsection{Electrophoresis techniques}

Electrophoresis techniques are suitable for obtaining an overview of the total genetic diversity of a soil microbial community. PCR products are separated by electrophoresis based on the nucleotide composition. The data of electrophoretic profiles, i.e., the position and the relative intensity of different bands or peaks, could be transferred to numerical data which is applicable for calculation of diversity indices and several statistical analyses and enable comparison of numerous samples.

Currently, three electrophoresis methods have been mainly used: denaturing gradient gel electrophoresis (DGGE) (Muyzer et al., 1993), terminal restriction fragment length polymorphism analysis (T-RFLP) (Dunbar et al., 2000), and automated ribosomal intergenic spacer analysis (ARISA) (Ranjard et al., 2001). These fingerprinting approaches are based on different principles (Fig. 5).

DGGE separates DNA fragments of the same size but of different sequence based on the melting behaviour of DNA: double strands of the AT base pair more easily disassociate than those of the GC base pair. During electrophoresis in a denaturing gradient acrylamide gel, an increasing denaturing environment, partially dissociates DNA double strands, creating diverse, branched molecules. The partial melting of DNA strands reduces mobility. Because the melting concentration of the denaturant is sequence-specific, different sequences of DNA fragments have different mobility in denaturing gels, and each DNA fragment can be seen as a distinct band in the gel. T-RFLP is modified from the conventional RFLP approach using fluorescently labelled PCR primers before restriction digestion and size detection of fluorescently labelled terminal restriction fragments using a DNA sequencer. ARISA is simple and discriminates the length of whole PCR amplicons, generally targeting highly variable ITS regions. Automated DNA sequencer technology is applied for T-RFLP and ARISA.

The three fingerprinting techniques have both advantages and disadvantages. One of the main advantages of gel-based community profiling techniques like DGGE enables sequence analysis of each band in a gel, and therefore, facilitates more detailed phylogenetic analysis. In T-RFLP, each T-RFLP peak can be identified by using database of T-RF length in various microbial groups. However, the inability to get sequence data from T-RFLP peaks makes it difficult to identify unknown species.

The use of an automated DNA sequencer significantly increases throughput of T-RFLP and ARISA compared with gel-based techniques. It also improves the accuracy in sizing general fragments through the inclusion of an internal standard in each sample. On the other hand, reproducibility between gels has been highlighted as one of main pitfalls of DGGE (Fromin et al., 2002). As comparison between several different gels is required when dealing with large sample numbers, it is critical to standardize the resolution and quality of gels and to use suitable internal standards for the accuracy of analyses. 


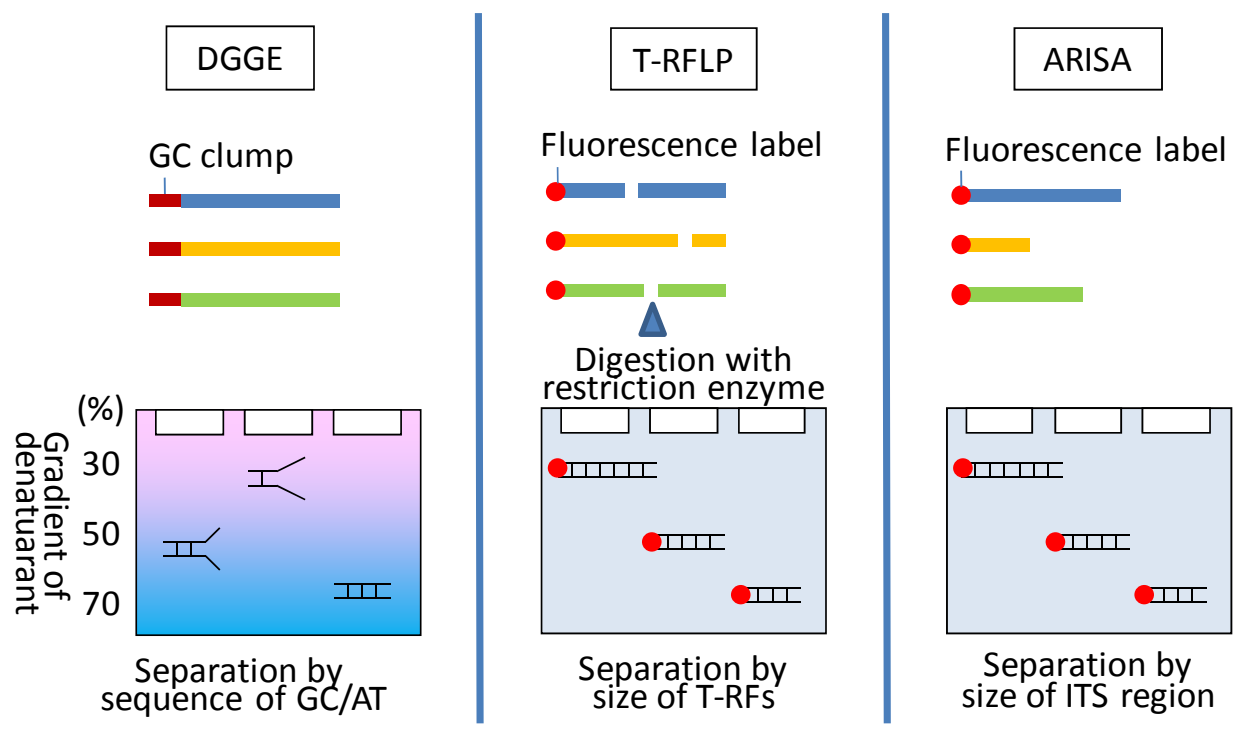

Fig. 5. Principles of three molecular fingerprinting methods

Okubo \& Sugiyama (Okubo \& Sugiyama, 2009) compared these fingerprinting methods, i.e., DGGE, T-RFLP and ARISA, by analyzing soil fungal communities. They reported that DGGE showed higher discrimination ability for soil fungal community rather than T-RFLP and ARISA, while ARISA exhibited the highest resolution ability.

From these properties, DGGE is suitable for analyses of highly heterogeneous communities including unknown members such as soil microbial community. T-RFLP is suitable for analyses of communities including known members and for specific taxonomic groups. ARISA appeared to be suitable for diversity analysis.

\subsubsection{Cloning and high-throughput sequencing technology}

Sequence-based community analyses can reveal fungal community structures with higher resolutions; fungal sequence data obtained can be identified or determined similarity to already known species through the use of extensive and rapidly growing sequence database (Nocker et al., 2007). Sequencing is the basis for construction of phylogenetic trees and for other comparative studies. Conversely, the sequence-based techniques are relatively time-consuming and costly. It depends on samples or target genes how many PCR amplicons were required to have fully analyzed the diversity contained within a single sample. Fierer et al. (2007) estimated that fungal $18 \mathrm{~S}$ rDNA richness at the $97 \%$ sequence similarity level is likely to exceed $10^{6}$ in $1.0 \mathrm{~g}$ of prairie soil, approximately $2 \mathrm{x}$ $10^{3}$ in rainforest soil and $2 \times 10^{4}$ in desert soil. Buée et al. (2009) reported that predicted richness of fungal ITS regions at the $97 \%$ sequence similarity level was approximately $2 \mathrm{x}$ $10^{3}$ in $4 \mathrm{~g}$ of forest soil.

Until recently, cloning and sequencing were primarily used to generate sequence data of environmental microbial community. PCR amplicons of rDNA and ITS region were cloned into an appropriate vector and clone libraries were sequenced by Sanger methods, also 
referred to as dideoxy chain termination sequencing (Sanger \& Coulson, 1975). During the current decade, high-throughput second-generation sequencing technologies, such as pyrosequencing, have been developed and introduced to the research of microbial ecology (Petrosino et al., 2009; Roesch et al., 2007), including fungal community analyses (Buée et al., 2009; Lim et al., 2010; Lumini et al., 2010). Buée et al. assessed the fungal diversity in six different forest soils using 454 pyrosequencing (Buée et al., 2009). No less than 166350 reads were obtained from all samples. It enables reading of hundreds, thousands of PCR amplicons per 1 run.

DNA pyrosequencing, sequencing by synthesis, was developed in the mid 1990s as a fundamentally different approach to DNA sequencing (Ronaghi et al., 1996). Sequencing by synthesis occurs by a DNA polymerase-driven generation of inorganic pyrophosphate, with the formation of ATP and ATP-depending conversion of luciferin to oxyluciferin. The generation of oxyluciferin causes the emission of light pulses, and the amplitude of each signal is directly related to the presence of one or more nucleotides. Pyrosequencing can eliminate time and labours for cloning and has the 10-fold cost advantage per base pair over Sanger sequencing. The use of primer barcoding techniques enables to characterize many environmental samples in parallel on a single sequencing run. One important limitation of pyrosequencing is its relative inability to sequence longer stretches of DNA. With first- and second-generation pyrosequenceing chemistries, sequences rarely exceed 100-200 bases. Because of this limitation, cloning and Sanger sequencing are applied for the accurate recovery of longer sequence data at this stage.

\section{Properties of PCR primers for fungal sequences}

For fungal community analyses, PCR-based techniques are most powerful and generally used. The $18 \mathrm{~S}$ rRNA gene (rDNA) and internal transcribed spacer (ITS) region are used widely as molecular markers for fungi, through the exploitation of both conserved and variable regions, and a large number of sequences are available in the data bank (Anderson \& Cairney, 2004). Various PCR primer sets targeting $18 \mathrm{~S}$ rDNA and ITS region are available for assessing fungal diversity in soil DNA samples (Table 1). Selection of PCR primer is one of the most important factors affecting outcome. Here, I will summerize their properties from our results and previous data.

\subsection{PCR amplification and chimera formation}

Although PCR-based strategies are the most powerful tools for the investigation of microbial diversity, they have a number of recognized limitations, perhaps the most insidious of which is the formation of recombinant or chimeric sequences during PCR amplification. Recombination can occur during PCR to jump from one template to another. Thus, whenever a heterogeneous pool of similar sequences, like rDNA and ITS regions, is amplified, chimera formation should be taken into account. The problem of chimeras in mixed DNAs from environmental samples has been highlighted several times in the literature (Kopczynski et al., 1994; Liesack et al., 1991; Wang \& Wang, 1997). The existence of chimeras in PCR products may result in the overestimation of community diversity (Wintzingerode et al., 1997) and the occurrence of artificial novel taxa (Jumpponen, 2007). Chimeras seem to comprise a large proportion of the environmental sequence data in public databases (Ashelford et al., 2005; Hugenholtz \& Huber, 2003). Jumppone (Jumpponen, 2007) 
reported that a large proportion (40 or 31\%) was chimeric in clone libraries obtained from soil fungal analyses.

\begin{tabular}{|c|c|c|c|}
\hline $\begin{array}{c}\text { Genomic } \\
\text { target }\end{array}$ & PCR primer & Primer sequence $\left(5^{\prime}-3^{\prime}\right)$ & reference \\
\hline \multirow[t]{15}{*}{$18 \mathrm{~S}$ rDNA } & NS1 & GTAGTCATATGCTTGTCTC & (White et al., 1990) \\
\hline & NS2 & GGCTGCTGGCACCAGACTTGC & \\
\hline & NS3 & GCAAGTCTGGTGCCAGCAGCC & \\
\hline & NS8 & TCCGCAGGTTCACCTACGGA & \\
\hline & EF3 & TCСТCTAAATGACCAAGTTTG & (Smit et al., 1999) \\
\hline & $\mathrm{EF} 4$ & GGAAGGGRTGTATTTATTAG & \\
\hline & Fung5 & GTAAAAGTCCTGGTTCCCC & \\
\hline & nu-SSU-0817 & TTAGCATGGAATAATRRAATAGGA & (Borneman \& Hartin, 2000) \\
\hline & nu-SSU-1196 & TCTGGACCTGGTGAGTTTCC & \\
\hline & nu-SSU-1536 & ATTGCAATGCYCTATCCCCA & \\
\hline & FR1 & AICCATTCAATCGGTAIT & (Vainio \& Hantula, 2000) \\
\hline & FF390 & CGATAACGAACGAGACCT & \\
\hline & Fun18S1 & CCATGCATGTCTAAGTWTAA & (Lord et al., 2002) \\
\hline & Fun18S2 & GCTGGCACCAGACTTGCCCTCC & \\
\hline & Fung & ATTCCCCGTTACCCGTTG & (May et al., 2001) \\
\hline \multirow[t]{10}{*}{ ITS } & ITS1 & TCCGTAGGTGAACCTGCGG & (White et al., 1990) \\
\hline & ITS2 & GCTGCGTTCTTCATCGATGC & \\
\hline & ITS4 & TCCTCCGCTTATTGATATGC & \\
\hline & ITS1F & CTTGGTCATTTAGAGGAAGTAA & (Gardes \& Bruns, 1993) \\
\hline & ITS4B & CAGGAGACTTGTACACGGTCCAG & \\
\hline & ITS4A & CGCCGTTACTGGGGCAATCCCTG & (Larena et al., 1999) \\
\hline & $2234 \mathrm{C}$ & GTTTCCGTAGGTGAACCTGC & (Sequerra et al., 1997) \\
\hline & $3126 \mathrm{~T}$ & ATATGCTTAAGTTCAGCGGGT & \\
\hline & PN3 & CCGTTGGTGAACCAGCGGAGGGATC & (Viaud et al., 2000) \\
\hline & PN34 & TTGCCGCTTCACTCGCCGTT & \\
\hline
\end{tabular}

Table 1. Sequences of PCR primers used for assessing soil fungal diversity

PCR protocol was reported to affect the frequency of chimera formation (Qiu et al., 2001; Wang \& Wang, 1997; Wintzingerode et al., 1997). To evaluate the significance of primer selection, we compared the compositions of $18 \mathrm{~S}$ rDNA libraries amplified from upland and paddy field soils using four primer sets: for single PCR, NS1/GCFung, FF390/FR1(N)-GC, and NS1/FR1(N)-GC; and for nested PCR, NS1/EF3 for the first PCR and NS1/FR1(N)-GC for the second PCR (Fig. 6) (Hoshino \& Morimoto, 2010). 


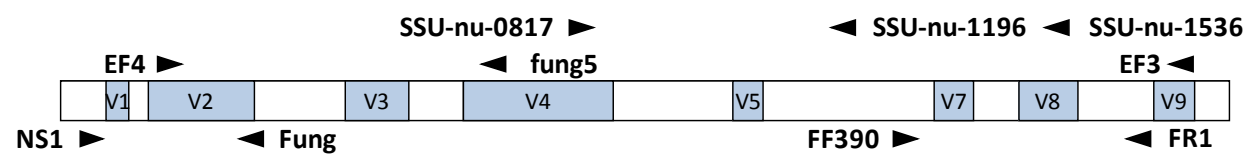

Fig. 6. Positions of PCR primers for fungal $18 \mathrm{~S}$ rDNA. The variable regions (V) are highlighted in blue

The frequency of chimera sequences was related to the length of target regions of each primer set (Table 2). Long amplicons (targeted by primer sets NS1/FR1(N)-GC and NS1/EF3 \& NS1/FR1(N)-GC) were more liable to produce chimeras than short amplicons (targeted by primer sets NS1/GCFung and FF390/FR1(N)-GC). Incomplete, prematurely terminated $18 \mathrm{~S}$ rDNA sequences were also more frequent in the libraries obtained with primer sets NS1/FR1(N)-GC and NS1/EF3 \& NS1/FR1(N)-GC. The concentration of amplified DNA initially increases exponentially and then gradually approaches a plateau when the depletion of reagents results in the generation of prematurely terminated strands. Such fragments seldom anneals with DNA strands of the same species among many homologous sequences of soil DNA (Torsvik et al., 1990), and the recombination events could be maximally expressed as chimeric molecules (Wang \& Wang, 1996).

\begin{tabular}{|c|c|c|c|c|c|c|c|c|c|c|c|}
\hline & \multirow[b]{2}{*}{ Primer set } & \multirow[b]{2}{*}{$\begin{array}{l}\text { Expected } \\
\text { products } \\
\text { size (bp) }\end{array}$} & \multirow[b]{2}{*}{$\begin{array}{c}\text { Number } \\
\text { of PCR } \\
\text { cycle }\end{array}$} & \multicolumn{4}{|c|}{ upland fiield soil } & \multicolumn{4}{|c|}{ paddy fiield soil } \\
\hline & & & & $\begin{array}{c}\text { mature } \\
18 S \\
\text { rDNA }\end{array}$ & $\begin{array}{c}\text { immature } \\
18 \mathrm{~S} \\
\text { rDNA }\end{array}$ & $\begin{array}{c}\text { chimeric } \\
185 \\
\text { rDNA }\end{array}$ & $\begin{array}{c}\text { non- } \\
18 \mathrm{~S} \\
\text { rDNA }\end{array}$ & $\begin{array}{c}\text { mature } \\
185 \\
\text { rDNA }\end{array}$ & $\begin{array}{c}\text { immature } \\
18 \mathrm{~S} \\
\text { rDNA }\end{array}$ & $\begin{array}{c}\text { chimeric } \\
18 S \\
\text { rDNA }\end{array}$ & $\begin{array}{c}\text { non- } \\
18 S \\
\text { rDNA }\end{array}$ \\
\hline 1 & NS1/GCFung & 350 & 30 & 94.6 & 0.0 & 5.4 & 0.0 & 95.5 & 1.1 & 3.4 & 0.0 \\
\hline 2 & FF390/FR1-GC & 390 & 40 & 89.0 & 0.0 & 9.9 & 1.1 & 89.9 & 2.2 & 7.9 & 0.0 \\
\hline 3 & NS1/FR1-GC & 1650 & 40 & 62.5 & 11.4 & 18.2 & 8.0 & 79.1 & 4.4 & 8.8 & 7.7 \\
\hline \multirow[t]{2}{*}{4} & NS1/EF3 & \multirow{2}{*}{1650} & 25 & \multirow{2}{*}{29.5} & \multirow{2}{*}{17.9} & \multirow{2}{*}{48.4} & \multirow{2}{*}{4.2} & \multirow{2}{*}{41.1} & \multirow{2}{*}{22.1} & \multirow{2}{*}{34.7} & \multirow{2}{*}{2.1} \\
\hline & NS1/FR1-GC & & 30 & & & & & & & & \\
\hline
\end{tabular}

Table 2. Composition of clone libraries obtained from upland and paddy field soils using primer sets 1. NS1/GCFung, 2. FF390/FR1(N)-GC, and 3. NS1/FR1(N)-GC; and for nested PCR, 4. NS1/EF3 for the first PCR and NS1/FR1(N)-GC for the second PCR. Figures indicated the percentage of the clones within each library (Hoshino \& Morimoto, 2010)

Our results indicated that the numbers of PCR cycle was also related to chimera formation (Table 2). Because the efficacy of PCR amplification differed among primer sets, we used 30, 40, and 40 cycles for primer sets NS1/GCFung, FF390/FR1(N)-GC, and NS1/FR1(N)-GC, respectively, to produce a sufficient amount of PCR products for DGGE. In the case of nested PCR, 25 cycles were made for first PCR using NS1/EF3, and 20 cycles for second PCR using NS1/FR1(N)-GC. The higher the number of PCR cycle, the higher the frequency of chimeras. These results suggested that a smaller number of PCR cycles worked better. When using primer sets FF390/FR1(N)-GC and NS1/FR1(N)-GC; however, high PCR cycle numbers are needed to obtain enough product, because the efficacy of the amplification is low (Hoshino \& Matsumoto, 2008).

Reducing chimera formation is required to provide a more accurate estimation of community diversity. Although the sequences with the potentiality of chimera could be identified and eliminated from data set, this procedure is often difficult and largely depends on personal judgement (Anderson \& Cairney, 2004). The existence of chimera sequences also reduced available data in clone libraries (Table 2). Our results showed that properties of 
primer sets affected the frequency of chimera formation and that PCR protocol may be modified to decrease PCR cycles and to extend elongation time so that chimera contamination may minimized. Thus, PCR efficacy is an important factor, as well as the length of target fragment.

\subsection{PCR primers specificity and bias in detection of fungal sequence from environmental samples}

For accurate fungal community analyses, desirable PCR primer sets could exhaustively amplify fungal sequences without bias and strictly avoid the amplification non-fungal sequences from DNA pools extracted from environmental samples. However, primer sets targeting fungal $18 \mathrm{~S}$ rDNA or ITS regions were designed for a broad range of fungi and consequently amplify genes of non-fungal organisms because of the high level of sequence similarity between $18 \mathrm{~S}$ rDNAs of fungi and some closely related eukaryotes (Anderson \& Cairney, 2004). Conversely, when increasing the specificity of primers for fungal genes, they may preferentially amplify a certain group of fungi, resulting in bias (Anderson \& Cairney, 2004).

We evaluated single and nested PCR systems in terms of the frequency of non-fungal sequences and the diversity of fungal sequences in clone libraries (Hoshino \& Morimoto, 2010). Four primer sets, i.e., for single PCR: NS1/GCFung, FF390/FR1(N)-GC, and NS1/FR1(N)-GC; and for nested PCR: NS1/EF3 for the first PCR and NS1/FR1(N)-GC for the second PCR, were compared using soil samples from upland and paddy fields. The rate of non-fungal eukaryotic $18 \mathrm{~S}$ rDNAs amplified by single PCR ranged between 7 to $16 \%$ for upland soil and between 20 to $31 \%$ for paddy field soil, whereas nested PCR produced a single eukaryotic clone in each library. The difference indicates that nested PCR increased the specificity to fungal sequences. Although the detection range of fungal taxa by $18 \mathrm{~S}$ rDNA was generally similar among primer sets for single PCR, the fungal community detected by nested PCR was biased to specific sequences: diversity indices were significantly lower than those from single PCR in both libraries. These differences indicate that nested PCR system using primer set NS1/EF3 \& NS1/FR1(N)-GC is not appropriate for diversity analysis on a wide range of taxonomic groups (i.e., total fungi).

The specificity of PCR primers varies depending on the composition of eukaryotic DNA contained in the extracted DNA pool. For example, although primer sets of EF4/EF3 and EF4/fung5 exclusively amplified fungal sequences from DNA extracted from wheat rhizosphere soil (Smit et al., 1999), they also amplified some non-fungal sequences from cultured organisms and avocado grove soil (Borneman \& Hartin, 2000). Single PCR primer sets, NS1/GCFung, FF390/FR1(N)-GC and NS1/FR1(N)-GC, amplified more clones of nonfungal eukaryotic from the paddy soil than from the upland soil (Table 3)(Hoshino \& Morimoto, 2010). These results may reflect the actual ratio of non-fungal related eukaryotic DNA to fungal DNA. In addition, phylogenetic groups of non-fungal eukaryotes detected were variable according to primer sets used (Table 3). The specificity of set NS1/FR1(N)-GC for fungi was higher than that of the other sets in the upland soil library but lower in the paddy soil library. The ratio of non-fungal gene preferentially detected by NS1/FR1(N)-GC was assumed to be higher in the DNA pool of paddy field soil than in that of upland field soil. Primer specificity is also affected by compositions of non-fungal eukaryotic sequences in samples. It showed that it is critical to check the specificity of primer sets for environmental samples to be studied. 
Anderson et al. (Anderson et al., 2003) reported that the relative proportion of sequences representing the four main fungal phyla was similar in clone libraries from grassland soil with primer sets nu-SSU-817/nu-SSU-1196, nu-SSU-817/nu-SSU-1536, EF4/EF3 and ITS1F/ITS4. On the other hand, Jumpponen (Jumpponen, 2007) reported that EF4/EF3 biased toward Basidiomycota as predicted (Smit et al., 1999) and that nu-SSU-817/nu-SSU1536 mainly amplified Ascomycota from soil samples of underneath willow canopies. We found that fungal 18S rDNA fragments showed a similar distribution at the phylum level in the upland and paddy soil libraries amplified with primer sets NS1/GCFung, FF390/FR1(N)-GC and NS1/FR1(N)-GC (Hoshino \& Morimoto, 2010). The detection frequency of the Chytridiomycota, however, differed among these primer sets. NS1/GCFung failed to detect the Chytridiomycota, while FF390/FR1(N)-GC amplified it more efficiently (Table 3). At the class level, especially in the paddy soil libraries, the difference was evident in the distribution of fungal taxa inferred from $18 \mathrm{~S}$ rDNA with these primer sets (Table 3). Primer selection has a pivotal importance on the community structure to be investigated although primer bias may not be as significant as previously thought, as Anderson et al. (Anderson et al., 2003) concluded.

\begin{tabular}{|c|c|c|c|c|c|c|c|c|c|c|c|c|}
\hline \multirow[b]{2}{*}{ kingdom } & \multirow[b]{2}{*}{ subkingdom } & \multirow[b]{2}{*}{ phylum } & \multirow[b]{2}{*}{ subphylum } & \multirow[b]{2}{*}{ class } & \multicolumn{4}{|c|}{ upland field soil } & \multicolumn{4}{|c|}{ paddy field soil } \\
\hline & & & & & 1 & 2 & 3 & 4 & 1 & 2 & 3 & 4 \\
\hline \multirow[t]{19}{*}{ fungi } & Dikarya & Ascomycota & Pezizomycotina & Dothideomycetes & 19 & 11 & 9.1 & 11 & 9.5 & 10 & 4.2 & 5.1 \\
\hline & & & & Eurotiomycetes & 3.4 & 3.7 & 5.5 & & & & 8.3 & \\
\hline & & & & Leotiomycetes & & & & & 25 & 14 & 4.2 & 2.6 \\
\hline & & & & Orbiliomycetes & & 3.7 & & & & 2.5 & & \\
\hline & & & & Pezizomycetes & 4.5 & 3.7 & 1.8 & & & & & \\
\hline & & & & Sordariomycetes & 27 & 35 & 42 & 29 & 2.4 & 8.8 & 8.3 & 5.1 \\
\hline & & & & unindentified & & & & & & 1.3 & & \\
\hline & & & & A cricomycets & 68 & 90 & 73 & 36 & 21 & 16 & 26 & 67 \\
\hline & & Basidiomycota & Basidiomycota & $\begin{array}{l}\text { Agricomycets } \\
\text { Tremellomycetes }\end{array}$ & 6.8 & 9.9 & $\begin{array}{l}7.3 \\
1.8\end{array}$ & 3.6 & $\begin{array}{l}21 \\
2.4\end{array}$ & $\begin{array}{l}16 \\
2.5\end{array}$ & $\begin{array}{l}26 \\
1.4\end{array}$ & b/ \\
\hline & & & Pucciniomycotina & Atractiellomycetes & & & & & 1.2 & & & \\
\hline & & & & Microbotryomycetes & & & & & & 2.5 & 1.4 & \\
\hline & incertae sedis & Chytridiomycota & & Chytridiomycetes & & 8.6 & 7.3 & & 1.2 & 6.3 & 1.4 & \\
\hline & & & & Monoblepharidomycetes & & & & & & & 1.4 & \\
\hline & & & & & & & & & & & & \\
\hline & & \multicolumn{2}{|l|}{ Blastocladiomycota } & Blastocladiomycetes & & & & & & & 1.4 & 2.6 \\
\hline & & incertae sedis & Mucoromycotina & Mucoromycetes & 22 & 15 & 18 & 57 & 6 & 16 & 11 & 15 \\
\hline & & & Zoopagomycotina & & & 1.2 & & & & & 1.4 & \\
\hline & & & Kickxellomycotina & & 1.1 & & & & & & & \\
\hline & & & & & & & & & & & & \\
\hline Amoebabiota & & Amoebazoa & & & & 1.2 & & & & & & \\
\hline Animalia & Amoebidiobiotina & Amoebidiozoa & & & & 1.2 & & & & & & \\
\hline \multirow[t]{2}{*}{ (=Metazoa) } & Bilateralia & Annelida & & & & & & & 25 & & 13 & \\
\hline & & Arthropoda & & & 1.1 & & & & & & & \\
\hline Rhizaria & & Cercozoa & & & 6.8 & 2.5 & 3.6 & & 1.2 & 19 & 9.7 & 2.6 \\
\hline Alveolata & & Apicomplexa & & & & & & & 3.6 & & & \\
\hline \multirow[t]{3}{*}{ stramenopiles } & & Oomycota & & & 8 & 1.2 & 1.8 & & & & 1.4 & \\
\hline & & Ochrophyta & & & & & & & 1.2 & & 4.2 & \\
\hline & & incertae sedis & & & & & 1.8 & & & & 1.4 & \\
\hline Plantae & & Viridiplantae & & & & & & & & 1.3 & & \\
\hline \multirow[t]{2}{*}{ incertae sedis } & & Apusozoa & & & & 1.2 & & & & & & \\
\hline & & Heliozoa & & & & 1.2 & & & & & & \\
\hline
\end{tabular}

Table 3. Distribution of $18 \mathrm{~S} r$ RNA gene sequenses in clone libraries from upland and paddy field soils using different primer sets for single PCR (1-3) and nested PCR (4), i.e., 1, NS1/GCFung; 2, FF390/FR1-GC; 3, NS1/FR1-GC; and 4, NS1/EF3 for first PCR and NS1/FR1-GC for second PCR. Figures indicated the percentage of the clones within each library 
These results indicate that appropriate primers should be selected according to the aims and the origin of samples and/or that more than two primer sets with different properties should be used to obtain a more comprehensive view of the fungal communities.

\subsection{Applicability for DGGE}

Community analysis by DGGE is sensitive to choice of primer sets because the separation of each DNA fragment in denetuaring gradient gels largely depends on the sequences of target regions. Okubo \& Sugiyama (Okubo \& Sugiyama, 2009) compared five fungal primer sets in terms of band separation of four fungal species in DGGE gels; when using EF4/GCFung, bands of the four species showed the same mobility in DGGE gels and were not separable, while they separated but smeared with EF4/Fung5 or ITS1F/ITS2-GC. On the other hands, NS1/GCFung and FF390/FR1-GC produced separate and single bands.

We evaluated primer sets for fungal 18S rDNA DGGE using agricultural soils in terms of the following features: detection and reproducibility of DGGE banding profiles, obtained diversity indices, and ability to discriminate fungal communities by DGGE (Hoshino \& Matsumoto, 2008). Four primer sets, i.e., for single PCR, NS1/GCFung, FF390/FR1(N)-GC, and NS1/FR1(N)-GC; and for nested PCR, NS1/EF3 for the first PCR and NS1/FR1(N)-GC for the second PCR, were compared using six soil samples from upland (F1, F2, F3 and F4) and paddy fields (P1 and P2) in Japan (Fig. 6).

PCR products with different primer sets under the appropriate experimental regimes showed clear band separation in DGGE analysis, as reported previously (May et al., 2001; Oros-Sichler et al., 2006; Vainio \& Hantula, 2000). In addition, repeated trials with the same samples produced virtually identical profiles in the same DGGE gels with primer sets NS1/GCFung and FF390/FR1(N)-GC. However, when primer set NS1/FR1(N)-GC was used, aggregates present in the middle of DGGE gel that sometimes interfered with the detection of target bands. We also detected smiling and distortion of banding patterns in DGGE with these primer sets. The presence of nonspecific aggregates and the distortion of banding pattern reduced reproducibility especially between different gels.

Although there was no significant difference in the number of bands that appeared in each sample among primer sets (Fig. 7A), the Shannon diversity indices, used to measure diversity in categorical data (Krebs, 1989), were lowest for primer set FF390/FR1(N)-GC, and tended to be higher for primer sets NS1/FR1(N)-GC and NS1/EF3 \& NS1/FR1(N)-GC (Fig. 7B). Two main bands were highly dominant in DGGE profiles of these six samples with primer set FF390/FR1(N)-GC. However, sequence diversity in clone library with primer set FF390/FR1(N)-GC was the higher than libraries with other primer sets (Hoshino \& Morimoto, 2010). The main reason for the difference may be ascribed to the low band separability in DGGE.

To evaluate the ability to discriminate fungal communities, multidimensional scaling (MDS) maps were generated from DGGE profiles for each primer set. Each MDS map showed a similar tendency (Fig. 8). Samples from upland and paddy field soils were positioned separately, with the exception of sample F4, which was always distant from other samples in the MDS maps. The MDS map with primer set NS1/GCFung showed the highest differentiation, with samples distantly located from one another, whereas with primer set FF390/FR1(N)-GC, except F4 differentiation among samples was lower in the MDS map. With primer set NS1/FR1(N)-GC, samples F1 and F3 and samples P1 and P2 were plotted close together. 
(A)

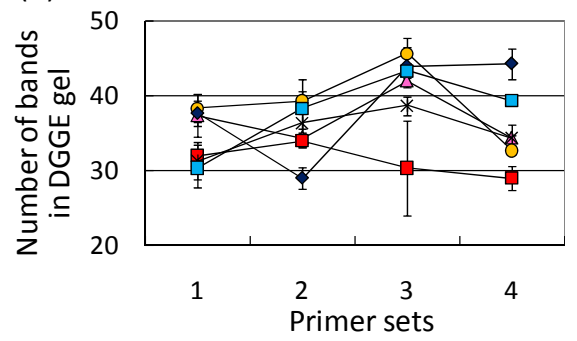

(B)

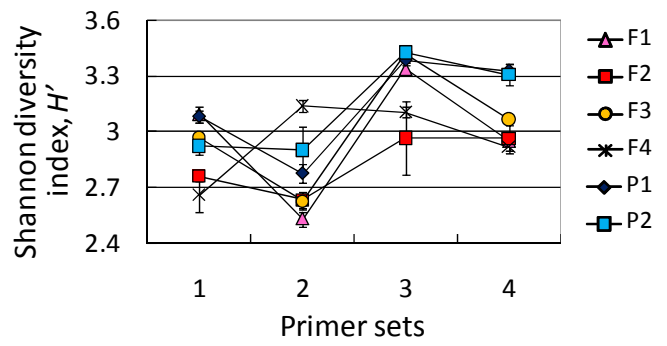

Fig. 7. Number of bands in DGGE gel (A), Shannon diversity index (B) of 185 rDNA DGGE profiles of upland field soils (F1, F2, F3, F4) and paddy field soils (P1, P2) using primer sets: 1. NS1/GCFung, 2. FF390/FR1(N)-GC, 3. NS1/FR1(N)-GC, and 4. NS1/EF3 for the first PCR and NS1/FR1(N)-GC for the second PCR (Modified from Fig. 4 in (Hoshino \& Matsumoto, 2008))

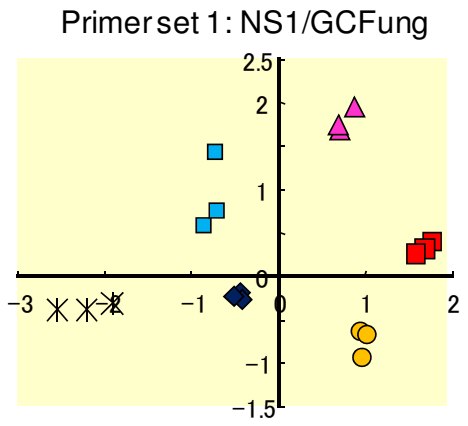

Primerset 3: NS1/FR1(N)-GC

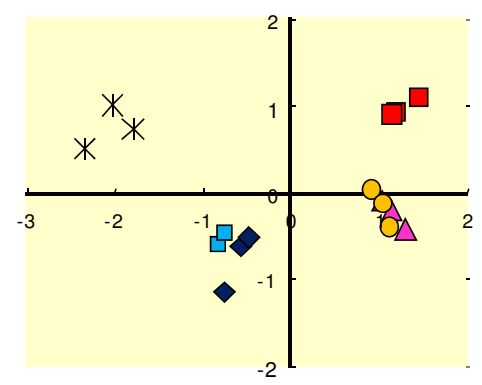

Primer set 2: FF390/FR1(N)-GC

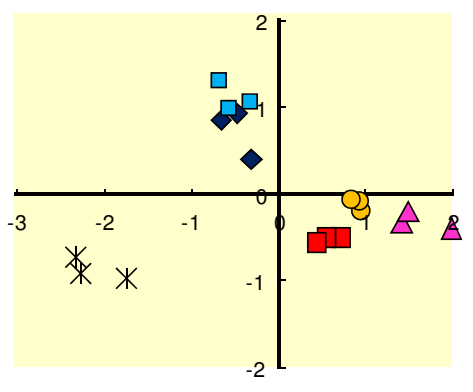

$\begin{array}{cc}\triangle & F 1 \\ \square & F 2 \\ \circ & F 3\end{array}$

Primerset 4:NS1/EF3 \& $\quad$ * F4 $\mathrm{NS} 1 / \mathrm{FR} 1(\mathrm{~N})-\mathrm{GC}$

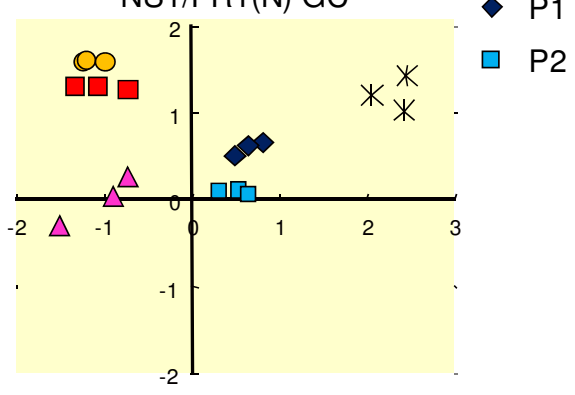

Fig. 8. Multidimensional scaling (MDS) map based on the squared distance of similarity of the 18S rDNA DGGE profiles of upland field soils (F1, F2, F3, F4) and paddy field soils (P1, P2) using primer sets: 1. NS1/GCFung, 2. FF390/FR1(N)-GC, 3. NS1/FR1(N)-GC, and 4.

NS1/EF3 for the first PCR and NS1/FR1(N)-GC for the second PCR (Modified from Fig. 5 in (Hoshino \& Matsumoto, 2008)) 
These data suggested that primer sets NS1/GCFung and FF390/FR1-GC were applicable for soil fungal community DGGE analysis and that primer set NS1/GCFung was the most suitable, considering all the various factors together. Comparison of DGGE profiles among each study is required to standardize experimental conditions, especially PCR primers. We selected primer set NS1/GCFung for this purpose and established DGGE experimental conditions using this primer set to prepare experimental protocols and technical reports of bacterial and fungal DGGE analyses (Morimoto \& Hoshino, 2010).

\section{Application examples of molecular techniques to fungal community analyses in agricultural field soils}

Molecular analyses of fungal community have been reported for various soils in different ecosystems, such as forests (Perkiömäki et al., 2003), grasslands (Brodie et al., 2003), dunes (Kowalchuk et al., 1997), and stream sediments (Nikolcheva et al., 2003), as well as agricultural fields (Gomes et al., 2003). In agricultural soils, many field trials have shown the effect of plant cultivation (Gomes et al., 2003), fertilizer and pesticide application on fungal community (Girvan et al., 2004). Here, I will show two examples of the application of molecular techniques to fungal community analyses in Japanese agricultural soils. We analyzed the impact of chemical fumigation on fungal community structure of bulk soil and spinach rhizosphere in a field and monitored their recovery from the drastic change (Hoshino \& Matsumoto, 2007). The results suggested that the effects were different among the chemicals and between bulk soil and rhizosphere. In addition, it was reported that fungal communities were most obviously affected by fertilizer treatment, i.e., changes in soil nutrient status, rather than edaphic factors such as soil type (Suzuki et al., 2009).

\subsection{Effect of chemical fumigants}

Pre-planting soil fumigation is used widely around the world in high-value crops and has been shown to be effective to control soil-borne pathogens, weeds, and plant-parasitic nematodes. In Japan, especially in areas that produce vegetables such as spinach, lettuce, and tomato, continuous monoculture is widely adopted to increase profit, often resulting in outbreak of pests. Many areas utilize soil chemical fumigation for consistent production. Most of chemical fumigants have a broad range of biocidal activity and can potentially harm beneficial organisms, in addition to target pests. Although methyl bromide (MeBr) had been widely used in the past, the use of $\mathrm{MeBr}$ in soil fumigation was banned since 2005 because of its environmental risk. Therefore, the use of alternatives, such as chloropicrin (CP) and 1,3-dichloropropene (1,3-D), has been increasing (Dungan et al., 2003). Their effect on nontarget organisms was also of concern and should be evaluated.

However, there are relatively few studies on the effect of chemical fumigants on non-target soil fungal community as compared with a number of studies reporting the effect on specific plant pathogens (Browning et al., 2006; Hamm, 2003; Takehara et al., 2003) and on bacterial community (Dungan et al., 2003; Ibekwe et al., 2001). Itoh et al. (Itoh et al., 2000) and Tanaka et al. (Tanaka et al., 2003) reported that the count of viable fungi decreased after CP fumigation. De Cal et al. (De Cal et al., 2005) used a culture-dependent method with selective media to show that chemical fumigants reduced certain members of soil fungi, such as Fusarium spp., Pythium spp., and Verticillium spp. We aimed to analyze the effect of 
two chemical fumigants (CP and 1,3-D) and spinach growth on fungal community structure in a field using molecular techniques (Hoshino \& Matsumoto, 2007).

Experiments were performed in an experimental field in Tsukuba, Japan. Annual cropping system consisted of soil fumigation in September followed by two consecutive spinach cultivations. Soil was treated with fumigants (CP at $20 \mathrm{ml} \mathrm{m}^{-2}$ or 1,3-D at $32 \mathrm{ml} \mathrm{m}^{-2}$ ) and covered with polyethylene film for about two weeks. Bulk soil and rhizosphere samples were taken periodically during the three fumigation trials. DNA was extracted directly from soil samples and fungal 18S rRNA genes were amplified by nested PCR with primer pairs AU2/AU4 and GC-FR1/FF390 for DGGE analyses. Dezitized data of DGGE profiles were analyzed by (i) diversity indices and (ii) multivariate statistical technique. Dominant bands in DGGE gels were excised for sequencing. Sequences of DGGE bands were identified with the FASTA search from the database of the DNA Data Bank of Japan (DDBJ).

(A)

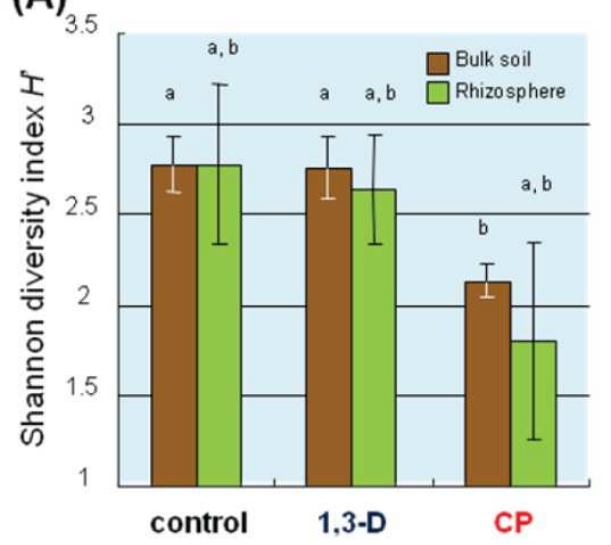

(B)

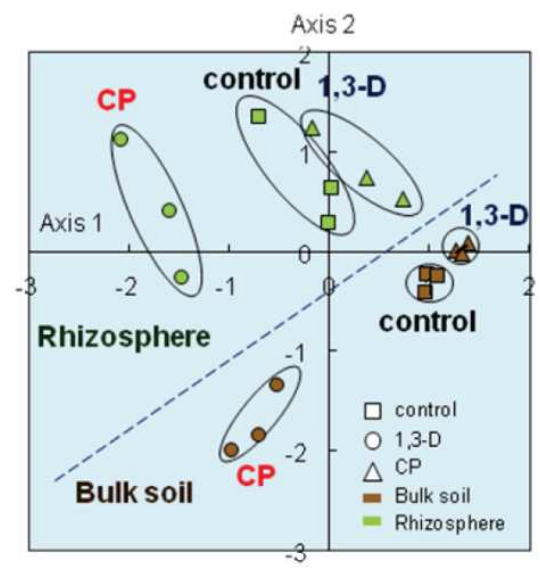

Fig. 9. Quantitative analysis of the $18 \mathrm{~S}$ rDNA DGGE profiles 2 months after fumigation in the second trial (year 2). (A) Shannon's diversity index and (B) multi-dimensional scaling (MDS) map based on the squared distance of similarity. (Modified from Fig. 3 in (Hoshino \& Matsumoto, 2007))

We compared the fungal $18 \mathrm{~S}$ rDNA DGGE profiles among each treatment two month after fumigation both in bulk soil and rhizosphere. The Shannon diversity index $H^{\prime}$ (Fig. 9A) was calculated from these profiles. The index for bulk soil in the $\mathrm{CP}$ plots was significantly lower than that in the control plots $(\mathrm{P}<0.05)$. The index for the rhizosphere soil in the $\mathrm{CP}$ plots also tended to be lower than that of control plots, but the difference was not significant. These values of the 1,3-D plots were almost equivalent to those of the control plots.

These DGGE profiles were also analyzed by multi-dimensional scaling (MDS) (Fig. 9B). The MDS map shows every band pattern on one plot, where relative changes in community structure can be visualized and interpreted as the distances between the points (Araya et al., 2003). The closer the points with each other, the more similar the DGGE banding patterns represented by the points are. In the MDS map, samples from the bulk soil and the 
rhizosphere soil were positioned separately, indicating that spinach cultivation affected soil fungal community structure, too (Fig. 9B). The MDS map also showed that the difference in DGGE profiles was greater between $\mathrm{CP}$ and control plots than between 1,3-D and control plots, both in bulk soil and rhizosphere soil (Fig. 9B). When the magnitude of the impact was compared between samples of bulk soil and rhizosphere soil, the differences in DGGE profiles between control and chloropicrin plots were smaller in rhizosphere soil than in bulk soil.

We monitored changes in fungal DGGE profiles in bulk soil after chemical fumigation of this field over three years. Fig. 10 shows the change in DGGE profiles of plots fumigated with chloropicrin or 1,3-D before fumigation, two months after fumigation, and six months after fumigation for each year. DGGE profiles drastically changed after CP treatment and did not recover completely 1 year after, e.g., before treatments in years 2 and 3 (Fig.10). In contrast, DGGE profiles of 1,3-D plots revealed a smaller change 2 months after fumigation but became indistinguishable from those of control plots after 6 months. These results indicated that the impact of fumigation on the soil fungal community was greater in the $\mathrm{CP}$ treatment than in the 1,3-D treatment both in terms of the magnitude of the effect after 2 months and the extent of recovery 1 year after.
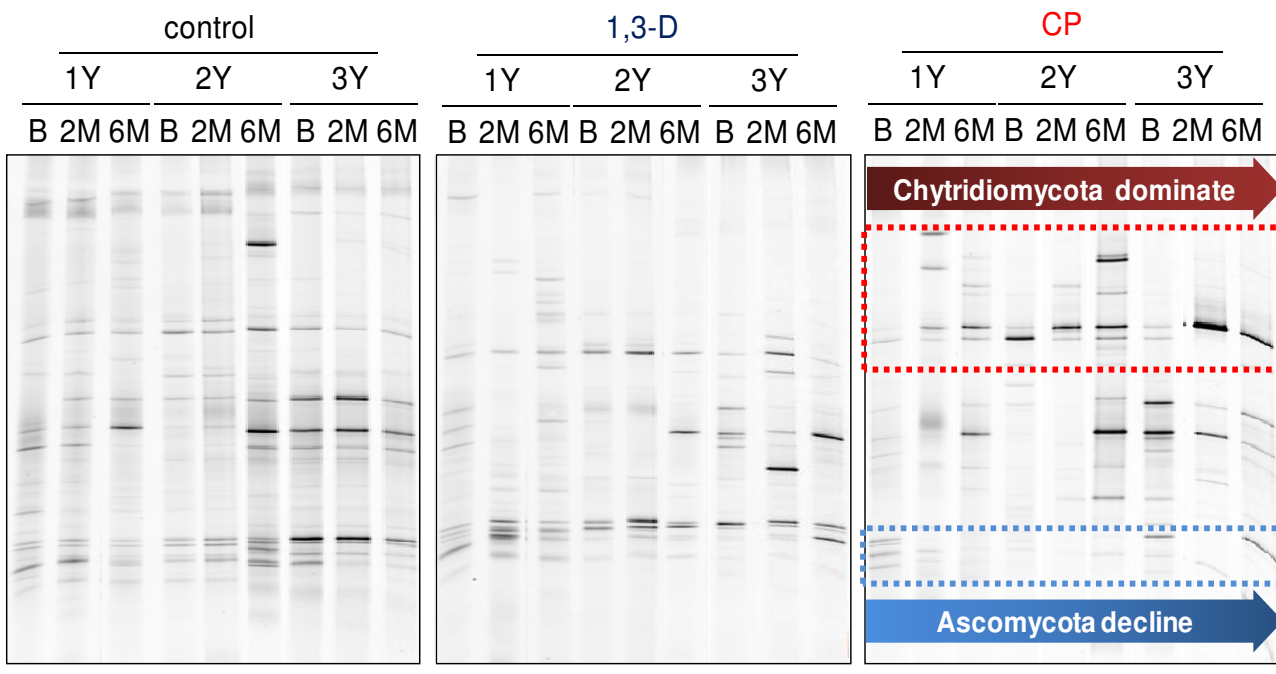

Fig. 10. Temporal change after fumigation in fungal $18 \mathrm{~S}$ rDNA DGGE profiles from bulk soil samples in (A) untreated control plot, (B) CP plot, and (C) 1,3-D plot. Samples were taken before (B) and 2 and 6 months (2M and $6 \mathrm{M}$, respectively) after fumigation for each year (1Y, $2 \mathrm{Y}$ and $3 \mathrm{Y}$ ) in three-year trials

Between treatments of $\mathrm{CP}$ and 1,3-D, there are differences in fungal species affected. In CPtreated plots, bands with high sequence similarity to Myrothecium cinctum $(100 \%$, Ascomycota), Bionectria ochroleuca (99.7\%, Ascomycota), Metarhizium anisopliae (100\%, Ascomycota), Dentipellisseparans (96.7\%, Basidiomycota), Verticillium dahliae (98.4\%, Ascomycota) and Exophiala dermatitidis (100\%, Ascomycota) decreased in band intensity. On 
the other hand, band intensity decreased in Basidiobolus microsporus (83.7\%, Basidiomycota) and Bensingtonia ciliate (88.9\%, Basidiomycota) in 1,3-D treated plots.

After CP treatment, bands inferred to represent chytridiomycota became dominant (Fig.10). Chytrids can rapidly reproduce and increase their populations in response to disturbance (Lozupone \& Klein, 2002). These characteristics could allow them to quickly exploit nutrients released after soil disturbance, such as fumigation, increasing their overall population. Chytridiomycota cannot be detected by conventional dilution-plate counting, and are usually studied using culture and microscopic protocols based on baiting techniques, using a "bait" substrate to attract chytrids under flooded conditions (Lozupone \& Klein, 2002). Our results indicated the advantages of molecular techniques to detect whole fungal community including such fungal groups.

\subsection{Effect of soil types and fertilizers}

Soil microbial communities are influenced by various factors such as cropping system (Kuske et al., 2002), tillage (Peixoto et al., 2006), fertilization (Marschner et al., 2003) and application of pesticide and herbicide (Yang et al., 2000). On the other hand, environmental factors, including soil characteristics, also affect microbial communities, e.g., soil type (Girvan et al., 2003), soil particle size (Sessitsch et al., 2001), soil air composition (Øvreås et al., 1998) and season (Girvan et al., 2004). Bacteria have been well documented for agricultural soils; many field trials have shown that the composition of the entire bacterial community is determined primarily by soil type (Girvan et al., 2003; Xu et al., 2009), emphasizing the effect of soil chemistry and structure, especially $\mathrm{pH}$ and soil texture (Fierer \& Jackson, 2006; Lauber et al., 2008), rather than cultural practices. However, little has so far been known about factors affecting fungal community structure.

Suzuki et al. (Suzuki et al., 2009) studied the effect of soil type and fertilizer type on bacterial and fungal communities in a long-term experimental field in Tsukuba, Japan. Upland field plots containing four different soil types, i.e., Gleyic Mollic-Umbric Andosols (Cumulic Andosol), Gleyic Haplic Andosols (Low-humic Andosol), Gleyic Haplic Alisols (Yellow Soil), and Entric Fluvisols (Gray Lowland Soil) were maintained under three different fertilizer management systems (chemical fertilizer rice husks plus cow manure, and pig manure) for 5 years. Carrot and maize were annually cropped in the fields once every summer. Bulk soil samples were taken in May prior to fertilization and cultivation. From directly-extracted soil DNA, bacterial 16S rDNA and fungal 18S rDNA were amplified using primer pairs 968g-GC/1378r and NS1/GCFung, respectively and subjected to DGGE analyses.

Fungal DGGE profiles based on the $18 \mathrm{~S}$ rRNA gene were analyzed by principal component analysis (PCA) to separate plots based on fertilization practices. This result showed that fungal community composition was more directly related to fertilization than soil type. On the other hand, PCA of bacterial DGGE profiles indicated that the plots were separated by soil type. Lauber et al. (Lauber et al., 2008) reported that fungal community composition was most closely associated with changes in soil nutrient status, i.e., concentration of total nitrogen and extractable phosphate, and the ratio of total carbon and nitrogen concentration. Suzuki et al. (Suzuki et al., 2009) described that fungi may be more suitable as microbial indicators of soil quality because the dynamics of fungal community were more reflected soil nutrient status than that of bacterial community. 


\section{Future perspectives}

PCR-based techniques targeting $18 \mathrm{~S}$ rDNA are powerful tools for fungal community analysis and have revealed phylogenetic compositions and dynamics of fungal communities in the environment. The accumulating molecular data has facilitated fungal community analyses on a large scale. Several previous reports, including examples shown in Section 4, have indicated that the fungal community could be substantially altered by cultural practices. However, most results were obtained from a few experimental fields. Large-scale and comprehensive analyses using enormous amounts of data on soils from various regions are required to determine whether the results presented in those reports are universally applicable or represent specific examples.

In Japan, the Environmental DNA database for agriculture soils (eDDASs) was established, which included not only DGGE profiles of bacteria, fungi and nematodes but also relevant information on soil, cultural practices, crop yield, etc. eDDASs facilitates large-scale analyses of the relationships between soil microbial communities and various environmental factors and may facilitate resolution of problems, such as disease forecasting, soil fertility evaluation, etc, in agricultural fields (Tsushima et al., 2011). The introduction of the next generation of sequencers combined with the development of bioinformatics tools will accelerate such large-scale analyses.

The abovementioned molecular techniques have limitations for the analyses of environmental fungal communities. The sequences of $18 \mathrm{~S}$ rDNA or ITS regions only reflect the phylogenetic positions of target microbes but not necessarily their metabolic functions. The existence of DNA in soil, even functional genes, only demonstrates the potential of fungal activity not a confirmation of its actual presence. Analyses based on the utilisation of soil RNA and/or other genetic markers associated with metabolic function should fortify fungal community analyses. The next step should focus on the functional aspects of fungal communities.

PCR can cause biased detections that prevent the complete recognition of microbial diversity through primer specificity and simultaneous amplification of different targets. New approaches that do not depend on PCR, such as metagenomic or metatranscriptomic analysis, can provide less biased data on fungal community structures and functional aspects, although some problems remain, particularly in data analyses (Suenaga, 2001). Currently, it is difficult to directly assign individual sequences that were directly recovered from soils or to construct contigs from them because a single soil sample may contain several thousand microbial genotypes, whereas most of their genomic sequences are still unrevealed.

The development of new molecular technologies should alleviate the problems associated with rDNA-based methods and PCR amplification and promote the investigation of current topics, such as the effect of pollution and global warming on fungal communities and their functions and roles in soil ecosystems.

\section{Conclusion}

Culture-independent molecular techniques, such as direct DNA extraction from soil followed by PCR-based community analysis techniques, provide novel insights and significant research advances in soil microbial ecology. Compared with bacterial communities, however, the results of soil fungal community analyses using molecular 
techniques are limited. One reason for these limitations is the lack of sufficient information, in the case of fungi, about the influence of various experimental parameters, particularly PCR primer selection, on the results of diversity studies.

We evaluated various PCR primer sets targeting the 18S rRNA gene (rDNA), a widely used molecular marker for fungi, as well as other experimental parameters and established a standard DGGE protocol for soil fungal community analysis. Molecular methods revealed that soil fungal communities were affected by cultural practices, such as chemical fumigation and fertilization, in agricultural fields. These techniques undergo constant improvement and should continue to promote research based on fungal ecology in soil ecosystems.

\section{Acknowledgment}

We thank Dr. Naoyuki Matsumoto (HokkaidoUniversity) for useful suggestions regarding an early draft of this manuscript. This work was partially supported by a Grant-in-Aid (Soil eDNA) from the Ministry of Agriculture, Forestry and Fisheries of Japan (eDNA-07-101-3).

\section{References}

Anderson IC \& Cairney JWG (2004). Diversity and ecology of soil fungal communities: increased understanding through the application of molecular techniques. Environmental Microbiology, Vol.6, No.8, (August 2004), pp. 769-779, ISSN 14622912

Anderson IC, Campbell CD \& Prosser JI (2003). Potential bias of fungal 18S rDNA and internal transcribed spacer polymerase chain reaction primers for estimating fungal biodiversity in soil. Environmental Microbiology, Vol.5, No.1, (January 2003), pp. 3647, ISSN 1462-2912

Araya R, Tani K, Takagi T, Yamaguchi N \& Nasu M (2003). Bacterial activity and community composition in stream water and biofilm from an urban river determined by fluorescent in situ hybridization and DGGE analysis. FEMS Microbiology Ecology, Vol.43, No.1, (February 2003), pp. 111-119, ISSN 0168-6496

Ashelford KE, Chuzhanova NA, Fry JC, Jones AJ \& Weightman AJ (2005). At least 1 in 20 $16 \mathrm{~S}$ rRNA sequence records currently held in public repositories is estimated to contain substantial anomalies. Applied and Environmental Microbiology, Vol.71, No.12, (December 2005), pp. 7724-7736, ISSN 0099-2240

Borneman J \& Hartin RJ (2000). PCR primers that amplify fungal rRNA genes from environmental samples. Applied and Environmental Microbiology, Vol.66, No.10, (October 2000), pp. 4356-4360, ISSN 0099-2240

Borneman J, Skroch PW, O'Sullivan KM , Palus JA, Rumjanek NG, Jansen JL, Nienhuis J \& Triplett EW (1996). Molecular microbial diversity of an agricultural soil in Wisconsin. Applied and Environmental Microbiology, Vol.62, No.6, (June 1996), pp. 1935-1943, ISSN 0099-2240

Brodie E, Edwards S \& Clipson N (2003). Soil fungal community structure in a temperate upland grassland soil. FEMS Microbiology Ecology, Vol.45, No.2, (July 2003), pp. 105114, ISSN 0168-6496

Browning M, Wallace DB, Dawson C, Alm SR \& Amador JA (2006). Potential of butyric acid for control of soil-borne fungal pathogens and nematodes affecting strawberries. 
Soil Biology and Biochemistry, Vol.38, No.2, (February 2006), pp. 401-404, ISSN 00380717

Buée M, Reich M, Murat C, Morin E, Nillson RH, Uroz S \& Martin F (2009). 454 Pyrosequencing analyses of forest soils reveal an unexpectedly high fungal diversity. New Phytologist, Vol.184, No.2, (October 2009), pp. 449-456, ISSN 14698137

Christensen M (1989). A view of fungal ecology. Mycologia, Vol.81, No.1, (March 1989), pp. 1-19, ISSN 0027-5514

De Cal A, Martinez-Treceno A, Salto T, Lopez-Aranda JM \& Melgarejo P (2005). Effect of chemical fumigation on soil fungal communities in Spanish strawberry nurseries. Applied Soil Ecology, Vol.28, No.1, (January 2005), pp. 47-56, ISSN 0929-1393

Dunbar J, Ticknor LO \& Kuske CR (2000). Assessment of Microbial Diversity in Four Southwestern United States Soils by $16 \mathrm{~S}$ rRNA Gene Terminal Restriction Fragment Analysis. Applied and Environmental Microbiology, Vol.66, No.7, (July 2000), pp. 29432950, ISSN 0099-2240

Dungan RS, Ibekwe AM \& Yates SR (2003). Effect of propargyl bromide and 1,3dichloropropene on microbial communities in an organically amended soil. FEMS Microbiology Ecology, Vol.43, No.1, (February 2003), pp. 75-87, ISSN 0168-6496

Fierer N \& Jackson RB (2006). The diversity and biogeography of soil bacterial communities. Proceedings of the National Academy of Sciences of the United States of America, Vol.103, No.3, (January 2006), pp. 626-631, ISSN $0027-8424$

Fierer N, Breitbart M, Nulton J, Salamon P, Lozupone C, Jones R, Robeson M, Edwards RA, Felts B, Rayhawk S, Knight R, Rohwer F \& Jackson RB (2007). Metagenomic and Small-Subunit rRNA Analyses Reveal the Genetic Diversity of Bacteria, Archaea, Fungi, and Viruses in Soil. Applied and Environmental Microbiology, Vol.73, No.21, (November 2007), pp. 7059-7066, ISSN 0099-2240

Fromin N, Hamelin J, Tarnawski S, Roesti D, Jourdain-Miserez K, Forestier N, TeyssierCuvelle S, Gillet F, Aragno M \& Rossi P (2002). Statistical analysis of denaturing gel electrophoresis (DGE) fingerprinting patterns. Environmental Microbiology, Vol.4, No.11, (November 2002), pp. 634-643, ISSN 1462-2912

Gardes M \& Bruns TD (1993). ITS primers with enhanced specificity for basidiomycetes application to the identification of mycorrhizae and rusts. Molecular Ecology, Vol.2, No.2, (April 1993), pp. 113-118, ISSN 0962-1083

Girvan MS, Bullimore J, Ball AS, Pretty JN \& Osborn AM (2004). Responses of Active Bacterial and Fungal Communities in Soils under Winter Wheat to Different Fertilizer and Pesticide Regimens. Applied and Environmental Microbiology, Vol.70, No.5, (May 2004), pp. 2692-2701, ISSN 0099-2240

Girvan MS, Bullimore J, Pretty JN, Osborn AM \& Ball AS (2003). Soil type Is the primary determinant of the composition of the total and active bacterial communities in arable soils. Applied and Environmental Microbiology, Vol.69, No.3, (March 2003), pp. 1800-1809, ISSN 0099-2240

Gomes NCM, Fagbola O, Costa R, Rumjanek NG, Buchner A, Mendona-Hagler L \& Smalla $\mathrm{K}$ (2003). Dynamics of fungal communities in bulk and maize rhizosphere soil in the tropics. Applied and Environmental Microbiology, Vol.69, No.7, (July 2003), pp. 3758-3766, ISSN 0099-2240 
Hamm PB, Ingham RE, Jaeger JR, Swanson WH \& Volker KC (2003). Soil fumigant effects on three genera of potential soilborne pathogenic fungi and their effect on potato yield in the columbia basin of oregon. Plant Disease, Vol.87, No.12, (December 2003), pp. 1449-1456, ISSN 0191-2917

Hoshino YT \& Matsumoto N (2004). An Improved DNA Extraction Method Using Skim Milk from Soils That Strongly Adsorb DNA. Microbes and Environments, Vol.19, No.1, (March 2004), pp. 13-19, ISSN 1342-6311

Hoshino YT \& Matsumoto N (2007). Changes in fungal community structure in bulk soil and spinach rhizosphere soil after chemical fumigation as revealed by $18 \mathrm{~S}$ rDNA PCR-DGGE. Soil Science and Plant Nutrition, Vol.53, No.1, (February 2007), pp. 4055, ISSN 0038-0768

Hoshino YT \& Matsumoto N (2008). Comparison of 18 S rDNA primers for estimating fungal diversity in agricultural soils using polymerase chain reaction-denaturing gradient gel electrophoresis Soil Science and Plant Nutrition, Vol.54, No.5, (October 2008), pp. 701-710, ISSN 0038-0768

Hoshino YT \& Morimoto S (2010). Soil clone library analyses to evaluate specificity and selectivity of PCR primers targeting fungal $18 \mathrm{~S}$ rDNA for denaturing-gradient gel electrophoresis (DGGE). Microbes and Environments, Vol.25, No.4, (December 2010), pp. 281-287, ISSN 1342-6311

Hugenholtz P \& Huber T (2003). Chimeric 16S rDNA sequences of diverse origin are accumulating in the public databases. International Journal of Systematic and Evolutionary Microbiology, Vol.53, No.1, (January 2003), pp. 289-293, ISSN 1466-5026

Ibekwe AM, Papiernik SK, Gan J, Yates SR, Yang C-H \& Crowley DE (2001). Impact of fumigants on soil microbial communities. Applied and Environmental Microbiology, Vol.67, No.7, (July 2001), pp. 3245-3257, ISSN 0099-2240

Itoh K, Takahashi M, Tanaka R, Suyama K \& Yamamoto H (2000). Effect of fumigants on soil microbial population and proliferation of Fusarium oxysporum inoculated into fumigated soil. Journal of Pesticide Science, Vol.25, No.2, (August 2000), pp. 147-149, ISSN 1348-589X

Jumpponen A (2007). Soil fungal communities underneath willow canopies on a primary successional glacier forefront: rDNA sequence results can be affected by primer selection and chimeric data. Microbial Ecology, Vol.53, No.2, (February 2007), pp. 233-246, ISSN 0095-3628

Kopczynski ED, Bateson MM \& Ward DM (1994). Recognition of chimeric small-subunit ribosomal DNAs composed of genes from uncultivated microorganisms. Applied and Environmental Microbiology, Vol.60, No.2, (February 1994), pp. 746-748, ISSN 0099-2240

Kowalchuk GA, Gerards S \& Woldendorp JW (1997). Detection and characterization of fungal infections of Ammophila arenaria (marram grass) roots by denaturing gradient gel electrophoresis of specifically amplified $18 \mathrm{~S}$ rDNA. Applied and Environmental Microbiology, Vol.63, No.10, (October 1997), pp. 3858-3865, ISSN 00992240

Kowalchuk GA, Drigo B, Yergeau E \& van Veen JA (2006): Assessing bacterial and fungal community structure in soil using ribosomal RNA and other structural gene markers. In: Nucleic Acids and Proteins in Soil, Nannipieri P \& Smalla K (Eds), 159188. Springer Berlin Heidelberg, ISBN 978-3-540-29448-1, Germany 
Krebs CJ (1989). (January 1989). Ecological Methodology, Harpercollins, ISBN 978-0060437848, New York

Kuske CR, Ticknor LO, Miller ME, Dunbar JM, Davis JA, Barns SM \& Belnap J (2002). Comparison of Soil Bacterial Communities in Rhizospheres of Three Plant Species and the Interspaces in an Arid Grassland. Applied and Environmental Microbiology, Vol.68, No.4, (April 2002), pp. 1854-1863, ISSN 0099-2240

Larena I, Salazar O, González V, Julián MC \& Rubio V (1999). Design of a primer for ribosomal DNA internal transcribed spacer with enhanced specificity for ascomycetes. Journal of Biotechnology, Vol.75, No.2-3, (October 1999), pp. 187-194, ISSN 0168-1656

Lauber CL, Strickland MS, Bradford MA \& Fierer N (2008). The influence of soil properties on the structure of bacterial and fungal communities across land-use types. Soil Biology and Biochemistry, Vol.40, No.9, (September 2008), pp. 2407-2415, ISSN 00380717

Liesack W, Weyland H \& Stackebrandt E (1991). Potential risks of gene amplification by PCR as determined by $16 \mathrm{~S}$ rDNA analysis of a mixed-culture of strict barophilic bacteria. Microbial Ecology, Vol.21, No.1, (December 1991), pp. 191-198, ISSN 00953628

Lim Y, Kim B, Kim C, Jung HS, Kim BS, Lee JH \& Chun J (2010). Assessment of soil fungal communities using pyrosequencing. The Journal of Microbiology, Vol.48, No.3, (June 2010), pp. 284-289, ISSN 1225-8873

Lord NS, Kaplan CW, Shank P, Kitts CL \& Elrod SL (2002). Assessment of fungal diversity using terminal restriction fragment (TRF) pattern analysis: comparison of $18 \mathrm{~S}$ and ITS ribosomal regions. FEMS Microbiology Ecology, Vol.42, No.3, (December 2002), pp. 327-337, ISSN 0168-6496

Lozupone CA \& Klein DA (2002). Molecular and cultural assessment of chytrid and Spizellomyces populations in grassland soils. Mycologia, Vol.94, No.3, (May - June 2002), pp. 411-420, ISSN 0027-5514

Lumini E, Orgiazzi A, Borriello R, Bonfante P \& Bianciotto V (2010). Disclosing arbuscular mycorrhizal fungal biodiversity in soil through a land-use gradient using a pyrosequencing approach. Environmental Microbiology, Vol.12, No.8, (August 2010), pp. 2165-2179, ISSN 1462-2912

Lyons JI, Newell SY, Buchan A \& Moran MA (2003). Diversity of Ascomycete laccase gene sequences in a southeastern US salt marsh. Microbial Ecology, Vol.45, No.3, (April 2003 ), pp. 270-281, ISSN 0095-3628

Marschner P, Kandeler E \& Marschner B (2003). Structure and function of the soil microbial community in a long-term fertilizer experiment. Soil Biology and Biochemistry, Vol.35, No.3, (March 2003), pp. 453-461, ISSN 0038-0717

Martin-Laurent F, Philippot L, Hallet S, Chaussod R, Germon JC, Soulas G \& Catroux G (2001). DNA extraction from soils: old bias for new microbial diversity analysis methods. Applied and Environmental Microbiology, Vol.67, No.5, (May 2001), pp. 2354-2359, ISSN 0099-2240

May LA, Smiley B \& Schmidt MG (2001). Comparative denaturing gradient gel electrophoresis analysis of fungal communities associated with whole plant corn silage. Canadian Journal of Microbiology, Vol.47(September 2001), pp. 829-841, ISSN 0008-4166 
Miller DN, Bryant JE, Madsen EL \& Ghiorse WC (1999). Evaluation and optimization of DNA extraction and purification procedures for soil and sediment samples. Applied and Environmental Microbiology, Vol.65, No.11, (November 1999), pp. 4715-4724, ISSN 0099-2240

Möhlenhoff P, Müller L, Gorbushina AA \& Petersen K (2001). Molecular approach to the characterisation of fungal communities: methods for DNA extraction, PCR amplification and DGGE analysis of painted art objects. FEMS Microbiology Letters, Vol.195, No.2, (February 2001), pp. 169-173, ISSN 0378-1097

Morimoto S \& Hoshino YT (November 2010). Technical Report on the PCR-DGGE Analysis of Bacterial and Fungal Soil Communities, In: National Institute for AgroEnvironmental Sciences, 02.09.2011, Available from

http://www.niaes.affrc.go.jp/project/edna/edna_jp/manual_bacterium_e.pdf

Muyzer G, de Waal EC \& Uitterlinden AG (1993). Profiling of complex microbial populations by denaturing gradient gel electrophoresis analysis of polymerase chain reaction-amplified genes coding for $16 \mathrm{~S}$ rRNA. Applied and Environmental Microbiology, Vol.59, No.3, (March 1993), pp. 695-700, ISSN 0099-2240

Nikolcheva LG, Cockshutt AM \& Bärlocher F (2003). Determining diversity of freshwater fungi on decaying leaves: comparison of traditional and molecular approaches. Applied and Environmental Microbiology, Vol.69, No.5, (May 2003), pp. 2548-2554, ISSN 0099-2240

Nocker A, Burr M \& Camper A (2007). Genotypic Microbial Community Profiling: A Critical Technical Review. Microbial Ecology, Vol.54, No.2, (August 2007), pp. 276-289, ISSN 0095-3628

Okubo A \& Sugiyama S (2009). Comparison of molecular fingerprinting methods for analysis of soil microbial community structure. Ecological Research, Vol.24, No.6, (November 2009), pp. 1399-1405, ISSN 0912-3814

Oros-Sichler M, Gomes NCM, Neuber G \& Smalla K (2006). A new semi-nested PCR protocol to amplify large $18 \mathrm{~S}$ rRNA gene fragments for PCR-DGGE analysis of soil fungal communities. Journal of Microbiological Methods, Vol.65, No.1, (April 2006), pp. 63-75, ISSN 0167-7012

Øvreås L, Jensen S, Daae FL \& Torsvik V (1998). Microbial Community Changes in a Perturbed Agricultural Soil Investigated by Molecular and Physiological Approaches. Applied and Environmental Microbiology, Vol.64, No.7, (July 1998), pp. 2739-2742, ISSN 0099-2240

Peixoto RS, Coutinho HLC, Madari B, Machado PLOA, Rumjanek NG, Van Elsas JD, Seldin L \& Rosado AS (2006). Soil aggregation and bacterial community structure as affected by tillage and cover cropping in the Brazilian Cerrados. Soil and Tillage Research, Vol.90, No.1-2, pp. 16-28, ISSN 0167-1987

Perkiömäki J, Tom-Petersen A, Nybroe O \& Fritze H (2003). Boreal forest microbial community after long-term field exposure to acid and metal pollution and its potential remediation by using wood ash. Soil Biology and Biochemistry, Vol.35, No.11, (November 2003), pp. 1517-1526, ISSN 0038-0717

Petrosino JF, Highlander S, Luna RA, Gibbs RA \& Versalovic J (2009). Metagenomic Pyrosequencing and Microbial Identification. Clinical Chemistry, Vol.55, No.5, (May 2009), pp. 856-866, ISSN 0009-9147 
Qiu X, Wu L, Huang H, McDonel PE, Palumbo AV, Tiedje JM \& Zhou J (2001). Evaluation of PCR-generated chimeras, mutations, and heteroduplexes with 16S rRNA genebased cloning. Applied and Environmental Microbiology, Vol.67, No.2, (February 2001), pp. 880-887, ISSN 0099-2240

Ranjard L, Lejon DPH, Mougel C, Schehrer L, Merdinoglu D \& Chaussod R (2003). Sampling strategy in molecular microbial ecology: influence of soil sample size on DNA fingerprinting analysis of fungal and bacterial communities. Environmental Microbiology, Vol.5, No.11, (November 2003), pp. 1111-1120, ISSN 1462-2912

Ranjard L, Poly F, Lata JC, Mougel C, Thioulouse J \& Nazaret S (2001). Characterization of Bacterial and Fungal Soil Communities by Automated Ribosomal Intergenic Spacer Analysis Fingerprints: Biological and Methodological Variability. Applied and Environmental Microbiology, Vol.67, No.10, (October 2001), pp. 4479-4487, ISSN 00992240

Robe P, Nalin R, Capellano C, Vogel TM \& Simonet P (2003). Extraction of DNA from soil. European Journal of Soil Biology, Vol.39, No.4, (October - December 2003), pp. 183190, ISSN 1164-5563

Roesch LFW, Fulthorpe RR, Riva A, Casella G, Hadwin AKM, Kent AD, Daroub SH, Camargo FAO, Farmerie WG \& Triplett EW (2007). Pyrosequencing enumerates and contrasts soil microbial diversity. The ISME Journal, Vol.1, No.4, (August 2007), pp. 283-290, ISSN 1751-7362

Ronaghi M, Karamohamed S, Pettersson B, Uhlén M \& Nyrén P (1996). Real-Time DNA Sequencing Using Detection of Pyrophosphate Release. Analytical Biochemistry, Vol.242, No1, (November 1996), pp. 84-89, ISSN 0003-2697

Sanger F \& Coulson AR (1975). A rapid method for determining sequences in DNA by primed synthesis with DNA polymerase. Journal of Molecular Biology, Vol.94, No.3, (May 1975), pp. 441-446, ISSN 0022-2836

Sequerra J, Marmeisse R, Valla G, Normand P, Capellano A \& Moiroud A (1997). Taxonomic position and intraspecific variability of the nodule forming Penicillium nodositatum inferred from RFLP analysis of the ribosomal intergenic spacer and Random Amplified Polymorphic DNA. Mycological Research, Vol.101, No.4, (April 1997), pp. 465-472, ISSN 0953-7562

Sessitsch A, Weilharter A, Gerzabek MH, Kirchmann H \& Kandeler E (2001). Microbial Population Structures in Soil Particle Size Fractions of a Long-Term Fertilizer Field Experiment. Applied and Environmental Microbiology, Vol.67, No.9, (September 2001), pp. 4215-4224, ISSN 0099-2240

Smit E, Leeflang P, Glandorf B, Dirk van Elsas J \& Wernars K (1999). Analysis of fungal diversity in the wheat rhizosphere by sequencing of cloned PCR-amplified genes encoding 18S rRNA and temperature gradient gel electrophoresis. Applied and Environmental Microbiology, Vol.65, No.6, (June 1999), pp. 2614-2621, ISSN 00992240

Suenaga H (2011). Targeted metagenomics: a high-resolution metagenomics approach for specific gene clusters in complex microbial communities. Environmental Microbiology, (March 2011), pp. 1-10, ISSN 1462-2920

Suzuki C, Nagaoka K, Shimada A \& Takenaka M (2009). Bacterial communities are more dependent on soil type than fertilizer type, but the reverse is true for fungal 
communities. Soil Science and Plant Nutrition, Vol.55, No1, (February 2009), pp. 8090, ISSN 1747-0765

Takehara T, Kuniyasu K, Mori M \& Hagiwara H (2003). Use of a nitrate-nonutilizing mutant and selective media to examine population dynamics of Fusarium oxysporum f. sp. spinaciae in soil. Phytopathology, Vol.93, No.9, (September 2003), pp. 1173-1181, ISSN 0031-949X

Tanaka S, Kobayashi T, Iwasaki K, Yamane S, Maeda K \& Sakurai K (2003). Properties and metabolic diversity of microbial communities in soils treated with steam sterilization compared with methyl bromide and chloropicrin fumigations. Soil Science and Plant Nutrition, Vol.49, No.4, (August 2003), pp. 603-610, ISSN 0038-0768

Thorn G (1997). The fungi in soil. In: Modern Soil Microbiology, van Elsas JD, Trevors JT \& Wellington EMH (Eds), 63-127. Marcel Decker, ISBN 978-0824794361, New York, USA

Tsushima S (March 2011). eDNA Database for Agricultural Soils, In: National Institute for Agro-Environmental Sciences, 02.09.2011, Available from

http://eddass.niaes3.affrc.go.jp/hp/index.html

Torsvik V, Goksøyr J \& Daae FL (1990). High diversity in DNA of soil bacteria. Applied and Environmental Microbiology, Vol.56, No.3, (March 1990), pp. 782-787, ISSN 00992240

Vainio EJ \& Hantula J (2000). Direct analysis of wood-inhabiting fungi using denaturing gradient gel electrophoresis of amplified ribosomal DNA. Mycological Research, Vol.104, No.8, (August 2000), pp. 927-936, ISSN 0953-7562

Vandenkoornhuyse P, Baldauf SL, Leyval C, Straczek J \& Yong JPW (2002). Extensive fungal diversity in plant roots. Science, Vol.295, No.5562, (March 2002), pp. 2051, ISSN 0036-8075

Viaud M, Pasquier A \& Brygoo Y (2000). Diversity of soil fungi studied by PCR-RFLP of ITS. Mycological Research, Vol.104, No.9, (September 2000), pp. 1027-1032, ISSN 09537562

Wang GC \& Wang Y (1996). The frequency of chimeric molecules as a consequence of PCR co-amplification of 16S rRNA genes from different bacterial species. Microbiology, Vol.142, No.5, (May 1996), pp. 1107-1114, ISSN 1350-0872

Wang GC \& Wang Y (1997). Frequency of formation of chimeric molecules as a consequence of PCR coamplification of $16 \mathrm{~S}$ rRNA genes from mixed bacterial genomes. Applied and Environmental Microbiology, Vol.63, No.12, (December 1997), pp. 4645-4650, ISSN 0099-2240

White TJ, Bruns T, Lee S \& Taylor J (1990) Amplification and direct sequencing of fungal ribosomal RNA genes for phylogenetic In: PCR Protocols: A Guide to Methods and Applications, Innis MA, Gelfand DH, Sninsky JJ \& White TJ (Eds), 315-322. Academic Press, ISBN 978-0123721808, New York, USA

Wintzingerode FV, Göbel UB \& Stackebrandt E (1997). Determination of microbial diversity in environmental samples: pitfalls of PCR-based rRNA analysis. FEMS Microbiology Reviews, Vol.21, No.3, (November 1997), pp. 213-229, ISSN 0168-6445

Xu Y, Wang G, Jin J, Liu J, Zhang Q \& Liu X (2009). Bacterial communities in soybean rhizosphere in response to soil type, soybean genotype, and their growth stage. Soil Biology and Biochemistry, Vol.41, No.5, (May 2009), pp. 919-925, ISSN 00380717 
Yang YH, Yao J, Hu S \& Qi Y (2000). Effects of Agricultural Chemicals on DNA Sequence Diversity of Soil Microbial Community: A Study with RAPD Marker. Microbial Ecology, Vol.39, No.1, (January 2000), pp. 72-79, ISSN 0095-3628

Yergeau E, Filion M, Vujanovic V \& St-Arnaud M (2005). A PCR-denaturing gradient gel electrophoresis approach to assess Fusarium diversity in asparagus. Journal of Microbiological Methods, Vol.60, No.2, (February 2005), pp. 143-154, ISSN 01677012 


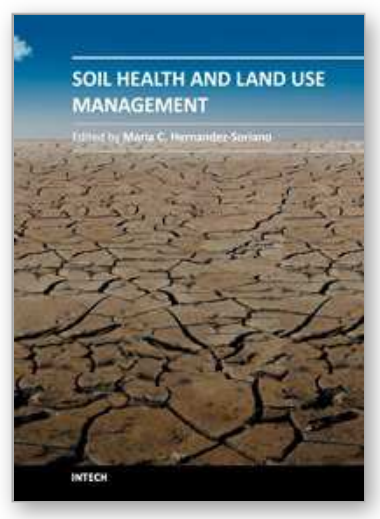

\author{
Soil Health and Land Use Management
}

Edited by Dr. Maria C. Hernandez Soriano

ISBN 978-953-307-614-0

Hard cover, 332 pages

Publisher InTech

Published online 25, January, 2012

Published in print edition January, 2012

Soils play multiple roles in the quality of life throughout the world, not only as the resource for food production, but also as the support for our structures, the environment, the medium for waste disposal, water, and the storage of nutrients. A healthy soil can sustain biological productivity, maintain environmental quality, and promote plant and animal health. Understanding the impact of land management practices on soil properties and processes can provide useful indicators of economic and environmental sustainability. The sixteen chapters of this book orchestrate a multidisciplinary composition of current trends in soil health. Soil Health and Land Use Management provides a broad vision of the fundamental importance of soil health. In addition, the development of feasible management and remediation strategies to preserve and ameliorate the fitness of soils are discussed in this book. Strategies to improve land management and relevant case studies are covered, as well as the importance of characterizing soil properties to develop management and remediation strategies. Moreover, the current management of several environmental scenarios of high concern is presented, while the final chapters propose new methodologies for soil pollution assessment.

\title{
How to reference
}

In order to correctly reference this scholarly work, feel free to copy and paste the following:

Yuko Takada Hoshino (2012). Molecular Analyses of Soil Fungal Community - Methods and Applications, Soil Health and Land Use Management, Dr. Maria C. Hernandez Soriano (Ed.), ISBN: 978-953-307-614-0, InTech, Available from: http://www.intechopen.com/books/soil-health-and-land-use-management/molecular-analysesof-soil-fungal-community-methods-and-applications

\section{INTECH}

open science | open minds

\section{InTech Europe}

University Campus STeP Ri

Slavka Krautzeka 83/A

51000 Rijeka, Croatia

Phone: +385 (51) 770447

Fax: +385 (51) 686166

www.intechopen.com

\section{InTech China}

Unit 405, Office Block, Hotel Equatorial Shanghai

No.65, Yan An Road (West), Shanghai, 200040, China 中国上海市延安西路65号上海国际贵都大饭店办公楼 405 单元

Phone: +86-21-62489820

Fax: +86-21-62489821 
(C) 2012 The Author(s). Licensee IntechOpen. This is an open access article distributed under the terms of the Creative Commons Attribution 3.0 License, which permits unrestricted use, distribution, and reproduction in any medium, provided the original work is properly cited. 